methodology of Soviet theoretical musicology: a collection of articles. Kyiv, pp. 5-17. [in Ukrainian].

4. Moskalenko, V. G. (1998). Do vyznachennia poniattia "muzychne myslennia" [To the definition of "musical thinking"]. Ukrainian musicology. (Eds.) I. Liashenko. Kyiv, Vol. 28, pp. 48-53. [in Ukrainian].

5. Petrushenko, V. L. (2000). Epistemologiia yak filosofska teoriia znannia : monohrafiia [Epistemology as a philosophical theory of knowledge: monograph].
Lviv : State University “Lviv Polytechnic”, 296 p. [in Ukrainian].

6. Yarko, M. I. \& Kavetska, V. V. (2017). Zvukovi ideyi novitnioho muzychnoho mystetstva [The ideas of sound in modern musical art: based on the concert program "Avant-garde (and not only) piano music of the $20^{\text {th }}$ century" performed by O. Striletska and O. Pozdnysheva]. Youth \& market. Issue 3 (68), 2017. pp. 35-43.[in Ukrainian].

УДК 378.37.01:78

DOI:

Чень Лян, аспірант факультету мистецтв імені Анатолія Авдієвського Національного педагогічного університету імені М.П. Драгоманова, м. Київ

\title{
ХУДОЖНЬО-ЦІННІСНА СФЕРА УЧИТЕЛІВ МУЗИКИ В КОНТЕКСТІ ФАХОВОЇ ПІДГОТОВКИ
}

Аналізується сутність художніх иінностей учителів музики: стосовно учителя як особистості $i$ стосовно його готовності до формування иінностей учнів. Показано відмінність традиційно музичних цінностей учителя музики і художніх иінностей як інтегрального феномена, щзо акумулює цінності з різних видів мистецтва; розглянуто його структуру. Проаналізовано потенціал дисциплін фахової підготовки (музично-теоретичних, музично-виконавських, музично-методичних) для формування художньо-иіннісної сфери студентів-музикантів.

Ключові слова: особистісні художні цінності; учитель музики; музична діяльність; поліхудожність.

Jim. 13.

Chen Lyan, Postgraduate Student of Faculty of Arts named after Anatoliy Avdiyevskiy, Mykhaylo Drahomanov National Pedagogical University, Kyiv

\section{ARTISTIC AND VALUE SPHERE OF MUSIC TEACHERS IN THE CONTEXT OF PROFESSIONAL TRAINING}

The essence of artistic values of music teachers is analysed: in relation to them as personalities and in relation to their readiness to formation the students' values. The author relies on the thesis that the professional activity of music teacher is a priori the artistic and aesthetic activity like the creative process of an artist with his or her inherent drama. The difference between traditional music values of music teacher and artistic values as an integral phenomenon that is dynamic, holistic, personally and professionally significant, permanently developed in the process of artistic cognition of works of different arts and characterized by semantic modernity for the subject; aims at self-improvement in the field of art around musical values, determines the effective and practical attitude to their spread in society. The semantic-component structure of the phenomenon (motivational-emotional, cognitivereflexive, practical-activity, artistic-communicative semantic components) is considered. The relevance of the factor "value polyartistic" in professional training of student-musician with a focus on the formation of musical values is emphasized. The specifics of different types of art from the standpoint of their mastery of personality are studied. The content of types of musical activity of student-musician is analysed: acquisition of knowledge about music, performance, analytical activities, verbal interpretation, research, lecture, pedagogical practices, based on the perception of music and projected into the plane of transmission of musical and aesthetic experience to future students. The value potential of disciplines of professional training (music-theoretical, music-performance, musicmethodological) for formation of artistic and value sphere of students is revealed. The core role of experience and artistic communication in the process of forming the teacher's personal values is proved.

Keywords: personal artistic values; a music teacher; musical activity; music-theoretical disciplines; musicperformance training; music-methodological training; polyartistic.

П

остановка проблеми. Визнані цінності мистецтва різних епох і національних культур акумулюють духовний досвід людства. Проте суперечливий інформаційний простір, в якому співіснують художні цінності й антицінності, загострюе проблему ціннісного формування особистості в соціокультурних реаліях. Учитель музики є носієм 
і транслятором цінностей до інших: коригує ціннісну сферу учнів і опосередковано через них впливає на художні процеси в суспільстві. Ця роль учителя детермінована його особистісними цінностями. Отже, щодо майбутніх учителів проблема художньо-ціннісного становлення суттєво актуалізується.

Аналіз основних досліджень і публікацій. Основоположна для мистецької освіти проблема цінностей цікавила людство завжди (М. Бердяєв, I. Кант, Конфуцій, А. Маслоу, Г. Мюнстерберг, К. Ушинський, П. Флоренський та ін.). Крім відображення в нормативних документах України і Китаю (Закон України “Про освіту”, Національна стратегія розвитку освіти України в 2012-2021 pp., концепція “Нової української школи”; Державна національна програма “Китай - XXI ст."; Стратегія розвитку освіти в Китаї в XXI ст.), конвенціях ЮНЕСКО ("Про охорону та заохочення розмаїття форм культурного самовираження" та ін.); означена проблема вивчається в естетико-мистецтвознавчому (I. Зязюн, М. Каган, С. Кримський, Л. Левчук, В. Медушевський та ін.), соціологічному (М. Вебер, Е. Носенко, М. Рокич, А. Ручка, Л. Юлдашев та ін.); культурологічному (Ю. Богуцький, О. Олійник, Г. Філіпчук та ін.); психолого-педагогічному (I. Бех, М. Боришевський, К. Журба та ін.) векторах, мистецькою педагогікою (О. Комаровська, Н. Миропольська, Г. Шевченко та ін.). Ці питання цікавлять китайських учених (Дунцзян Цзяо, Чжан Бодуань, Цзінь Сіньсінь, Чен Чжуньїн та ін.), дослідників, які вивчають культуру Китаю (М. Алексєєва, Т. Ринчинова, Л. Янгутов та ін.).

Автори зосереджуються переважно на музичних цінностях, натомість феномен художніх цінностей педагога-музиканта поки досліджений мало.

Мета статті - розкрити сутність феномена особистісних художніх цінностей стосовно майбутніх учителів музики, визначити змістові чинники їх утворення у різних видах музичноосвітньої діяльності.

Виклад основного матеріалу. Особистісні художні цінності розуміємо як результат привласнення суб'єктом цінностей об'єктивних, визнаних у загальнолюдському вимірі - як їх емоційне переживання і рефлексію. Завдяки цьому вони стають частиною внутрішнього світу, відповідно до якого людина визначає пріоритети своєї поведінки і життєтворчості загалом [5]. Особистісні художні цінності вчителя музики збігаються з професійно-педагогічними, сутність яких міститься на перетині його власне художніх цінностей, що спонукають до творчої самореалізації, та змісту професійної діяльності, зокрема у впливі на особистісні художні цінності учнів, що спонукатимуть до самореалізації уже їх. При цьому професійна діяльність учителя музики є художньо-естетичною; вона подібна до творчого процесу з драматургією, властивою творенню художнього образу. Як вказує С. Соломаха, діяльність учителів мистецтва створює в освітньому закладі специфічне художньо-естетичне поле, яке спрямоване на збагачення і коригування "аксіосфери” - “у вигляді ціннісних уявлень, оцінок, смаків, ідеалів, норм, канонів, моделей поведінки, психологічних механізмів дій тощо, які носять гуманістичний характер і відіграють роль світоглядних життєвих орієнтирів особистості” $[8,8]$.

Цінності, якими має оволодіти педагог будьякого фаху, на думку I. Беха, постають як “регулятор людської життєдіяльності”, що охоплює і об'єктивну дійсність, тобто зовнішній світ, і “власне людину в усіх її об'єктивних характеристиках” $[1,138]$. Натомість І. Зязюн, уважає їх ланкою, яка поєднує особистісні смисли 3 поширеними в суспільстві, і в такий спосіб спрямовують функціонування культури, зумовлюючи їхню передачу крізь покоління; цінності і смисли складають “ядро освіти”, яка $\epsilon$ “культурним процесом”, в якому транслюються культурні цінності [4, 235].

Художні цінності майбутніх учителів музики, як иінності передусім музичні, безпосередньо формуються у різних видах музичної діяльності: набутті знань про музику; виконавській та інтерпретаційно-аналітичній діяльності, що спирається на розвиток сприймання музики i проєктується на передачу музично-естетичного досвіду учням. Така діяльність реалізується в аудиторній та позааудиторній роботі майбутніх педагогів-музикантів, охоплює музичнотеоретичні, музично-виконавські, музичнометодичні дисципліни та пов'язані з ними практики - педагогічну, лекційну, науково-дослідницьку, участь у концертній діяльності тощо.

Змістове поле знань про музичне мистецтво охоплює музичні явища, що перебувають у центрі уваги в усіх курсах професійної підготовки. Але домінантно - в процесі опанування музичнотеоретичних дисицилін: студенти-музиканти ознайомлюються 3 творами стильових епох та національних культур, теорією музики; закономірностями історико-культурних процесів. Системно це відбувається як через сприймання та оволодіння інформацією про твори, так і через задіяні виконавські уміння (у практичних 


\section{ХУДОЖНЬО-ЦІННІСНА СФЕРА УЧИТЕЛІВ МУЗИКИ В КОНТЕКСТІ ФАХОВОӤ ПІДГОТОВКИ}

демонстраціях теоретичних висновків аудиторії однокурсників тощо). Суттєвою для формування ціннісної сфери $є$ вербальна інтерпретація творів як діяльнісне донесення смислів до слухацької аудиторії; уміння такої діяльності також пріоритетно формуються під час опанування музично-теоретичних дисциплін; інтерпретація буде досконалішою, якщо майбутній педагогмузикант уміє донести власні судження до інших, емоційно заразити ними. Отже, невід'ємним складником підготовки вчителів музики в напрямі формування цінностей і здатності впливати на цінності інших є лекторські уміння у комплексі вербальних та невербальних складників, які посилюють емоційність та виразність художньої комунікації [10]. Практико-орієнтована спрямованість музично-теоретичної підготовки передбачає реалізацію здобутих знань і в опануванні арт-терапевтичних практик, імпровізації та композиторській творчості, оволодінні основами звукорежисури, у фольклорних експедиціях тощо. На цьому ж базується й успішність педагогічної практики музикантів та професійне ствердження у виконавстві.

Музично-виконавська підготовка майбутніх учителів музики охоплює оволодіння майстерністю гри на різних інструментах соло або в ансамблях / оркестрах, вокальній або вокальноінструментальних формах виконавства, диригентстві (хоровому або оркестровому), концертмейстерстві тощо. До того ж, музичновиконавська підготовка містить необхідний теоретичний компонент знань про виконавство і його закономірності. Виконавська інтерпретація музичних творів завжди є забарвленою емоційним досвідом виконавця, його власними цінностями і завжди адресована слухачам, у чому полягає суть виконавства [6]. Оволодіння виконавською майстерністю уможливлює переконливу передачу іншим багатства світу своїх цінностей через одночасне зі сприйманням і творенням образу “емоційне зараження" творчістю [5]. Участь майбутнього педагога-музиканта в оркестрі чи ансамблевому музикуванні, концертмейстерська підготовка, крім суто музично-виконавських досягнень, передбачає і формує здатність художнього партнерства на сцені і під час підготовки до сценічного виступу [13], комунікативні здібності, що принципово для впливу на цінності учнів. Набуття виконавських умінь і сценічного досвіду бути впевненим і переконливим у донесенні знань про музику та інтерпретацій до публіки, доповнюючи вербальне спілкування.
Зміст музично-методичної підготовки майбутніх учителів музики визначається на перетині теорії і практики; під теорією розуміємо музично-теоретичну і загальнопедагогічну підготовку, знання з методики навчання музики, дитячого пісенного репертуару; а під практикою педагогічну практику в закладах освіти. T. Бодрова справедливо наполягає на встановленні у змісті такої підготовки та його реалізації “методично обгрунтованих зв'язків між предметами мистецького циклу (музичнотеоретичними дисциплінами, методикою постановки голосу, грою на музичному інструменті, диригентсько-хоровим класом) та курсом методики музичної освіти дітей шкільного віку”, причому такі зв'язки позначаються як “внутрішньо-дисциплінарний синтез” із причиннонаслідковими відношеннями елементів [2, 29; 31], 3 чим, безумовно, погоджуємось.

Відзначаючи ціннісну функцію практичної підготовки учителів музики, І. Дікун розглядає її в цілісній системі, що охоплює виробничу практику і практику виховної роботи 3 дошкільнятами і школярами; фольклорну практику; літню виробничу практику в дитячих оздоровчих закладах; практику диригентсько-хорову, переддипломну; науково-дослідницьку тощо; але суттєво, що досягнення у практично-педагогічній підготовці пов'язуються з формуванням творчих якостей педагога-музиканта - як можливість і площина для самовдосконалення в професії, що, на нашу думку, невід'ємно від ціннісного становлення вчителів музики $[3,15]$.

Водночас поняття “художні цінності” $€$ ширшими, ніж цінності суто музичні; вони конкретизується як цінності 3 різних видів мистецтва, потребуючи від учителя музики свого роду ціннісної “поліхудожності”, яка в тому числі стосується і здійснення ним педагогічних впливів на художні цінності учнів. Отже, в змісті особистісних художніх цінностей вчителя музики проакцентуємо доцільність мотивування їх до пізнання творів різних видів мистецтва, незалежно від обраної спеціалізації педагога-музиканта як основу загальномистецького світогляду, що впливає на його життєтворчість загалом; а також таку організацію поліхудожньої підготовки студентів-музикантів, яка центрована на їх музичному зростанні і реалізується у зв'язках різних мистецтв 3 музикою як змістовим стрижнем формування художніх цінностей [12]. Як стверджує О. Реброва, для художньоментальних процесів генералізованою ознакою $є$ “поліхудожня орієнтація, яка формується під впливом мистецької інтеграції та синестезії 


\section{ХУДОЖНЬО-ЦІННІСНА СФЕРА УЧИТЕЛІВ МУЗИКИ В КОНТЕКСТІ ФАХОВОЇ ПІДГОТОВКИ}

сприйняття, відчуття, інтерпретації мистецьких творів" тощо [9, 44].

Наголосимо, що твори таких видів мистецтва, як театр, хореографія, екранні мистецтва, цирк тощо є синтетичними за природою, а отже, людина, занурюючись у них як глядач, апелює до синтезу мистецтв, інакше унеможливлюється повноцінне прийняття творів як художньої цінності. Пізнаючи твори будь-якого мистецтва і привласнюючи їх як особистісну цінність, людина так чи так декодує широкий спектр цінностей загальнолюдських; у такий спосіб, через твір будь-якого мистецтва в особистості утворюється багатогранна художня картина світу, в якій задіяні образи слухові, зорові, тактильні, кінестетичні тощо. Тобто цілісна художня картина світу постає i як результат поєднання цінностей з різних мистецтв навколо музичних цінностей, і як підгрунтя для їхнього утворення [5; 7; 9 та ін.].

У зв' язку з цим зауважимо: всі види мистецтва мають різну природу, але спільну “одиницю” художнього висловлювання - художній образ, який твориться різними виразними засобами (Ю. Борєв, М. Каган, О. Крівцун, Л. Левчук та ін.). Вибір особистістю творів певного мистецтва для сприймання або практичного занурення детермінований іiї здібностями, уподобаннями, мотивами або вольовими спрямуваннями до пізнання. Врахування специфіки видів мистецтва $€$ важливим для розуміння механізмів утворення особистісних цінностей під час пізнання творів цих мистецтв, що активно досліджується вченими. Все ж звернімо окрему увагу на такі дискусійні і не завжди визначені в ціннісному плані видовищні форми сучасного мистецтвв, як хепенінг, флешмоб, перформанс, інсталяція, графіті, бодіарт, стріт-арт, карнавали та різноманітні театралізовані мистецькі вуличні акції і вуличне мистецтво, відеоігри, пісочна анімація, талант-шоу, реаліті-шоу тощо, адже вони все більше приваблюють молодь. К. Станіславська на підставі аналізу естетичної сутності та історичних витоків таких форм констатує: “мистецьковидовищна форма - це художня структура, що поєднує систему мистецьких засобів виразності із зовнішнім видовищним виявом" $[11,25]$. Такі форми $є$ колективними і публічними, свого роду “театралізацією життя”, мають ознаки гри і розраховані на сприймання великою аудиторією одночасно; багато з них передбачає залучення глядачів як учасників. Разом це посилює емоційність сприймання і співпереживання у процесі творення - подібно до театрального мистецтва. К. Станіславська уточнює, що кожна така форма має “свою філософію, правила, техніку та етикет, сформовані традиції побутування тобто всі риси, властиві будь-якому конструктивному явищу культури" $[11,113]$.

На наше переконання, вказані та інші форми, що динамічно змінюються, миттєво відображуючи зміни в художньо-інформаційних процесах, посилюють акценти їх ціннісної ідентифікації: адже не все, чим насичується простір, насправді може являти художню цінність; зі значною вірогідністю деякі прояви можуть нести негативний емоційний заряд. А це висуває посилені вимоги до формування в особистості ціннісного й вибіркового ставлення до явищ сучасного мистецтва i сучасного інформаційного простору [5].

Правомірним також є висновок О. Комаровської [5]: присутність творів певного виду мистецтва серед особистісних цінностей або ж відсутність уподобань у певному мистецтві (стилі, жанрі) не може слугувати індикатором змістовності художньо-ціннісної сфери будь-якої людини. Але для вчителя музики різновекторність художнього пізнання є принциповою; він має бути обізнаним у колі цінностей учнів і здатним коригувати вплив інформаційного простору на їх внутрішній світ. Тому розвиток здатності емоційного сприйняття творів різних мистецтв є суттєвим для вчителя музики, незалежно від того, якими здібностями, крім власне музичних, він володіє і чи все з творів і мистецьких явищ, з якими він ознайомлюється, стало його особистісними цінностями. Тобто для вчителя музики набуває ціннісного сенсу сам факт поліхудожнього пізнання, націлений на спілкування 3 учнями щодо мистецтва, їх уподобань, смаків, цінностей.

Таким чином, художні цінності майбутніх учителів музики є динамічним, цілісним, особистісно і професійно значущим феноменом, що має на меті самовдосконалення навколо музичних цінностей і перманентно формується у пізнанні творів різних мистецтв, характеризується смисловою сучасністю для суб' єкта; детермінує дієво-практичне ставлення до їх поширення у суспільстві. Маємо підстави для виокремлення компонентно-змістової структури феномена, а саме компоненти:

- мотиваційно-емоційний (емоційність реагування на твори; мотивація переживати і осмислювати нові твори, які перебувають у “звичному” або “незвичному” смисловому полі; враховується можлива вибірковість емоційного прийняття творів різних видів, жанрів, стилів тощо;

- когнітивно-рефлексивний (обізнаність у галузі різних мистецтв -творів, авторів, особливостей мови різних мистецтв, художніх стилів і напрямів, особливостей мистецтва рідної 
та різних етнонаціональних культур тощо); (здатність осмислювати пізнане і самовизначатись у ставленні до явищ художньо-інформаційного простору, аналізувати вплив творів на себе);

- практико-діяльнісний (уміння інтерпретації смислів, закладених у твори; уміння творення художніх образів, зокрема в різних мистецтвах; націленість на креативну самореалізацію у конкретному мистецтві);

- художньо-комунікативний (налаштованість носія цінностей до діалогу з творами мистецтва різних видів та до міжособистісного діалогу щодо мистецтва; уміння вербальної і невербальної комунікації під час діалогу).

Висновки і перспективи дослідження. Сформованість ціннісної сфери вчителя музики означає, що, крім привласнення власне музичних творів як цінності, у нього мають бути сформовані ціннісні установки на художнє пізнання творів різних видів мистецтва, що охоплює художню емпатію і рефлексію, художню комунікацію у різних іпостасях, мотивацію до мистецької діяльності; до художніх цінностей учителя включаються цінності його діяльності як художньо-естетичної і спрямованої на формування художніх цінностей учнів.

Подальше дослідження проблеми потребує розроблення технологій ціннісно-особистісного становлення та відповідних методик комплексної підготовки вчителів на засадах аксіологічного підходу, що проєктується на привласнення творів різних мистецтв як професійно-педагогічної необхідності в комплексі змісту всіх дисциплін, які опановують майбутні педагоги.

\section{ЛІТЕРАТУРА}

1. Бех І. Д. Виховання особистості : сходження до духовності. Київ: Либідь, 2006. 272 с.

2. Бодрова Т. О. Методична підготовка майбутніх учителів музики в контексті універсальних принципів загальної та мистецької освіти. Innovative processes in education: Collective monograph. AMEET Sp. z o.o., Lodz, Poland, 2017. pp. 26-39.

3. Дікун І.А. Формування досвіду творчої діяльності майбутніх учителів музики у процесі педагогічної практики: автореф. дис.... канд. пед. наук: 13.00.02. - Теорія та методика музичного навчання. НПУ імені М. П. Драгоманова Київ, 2018.20 c.

4. Зязюн І. А. Універсальність та інтегративність культури в освітньому просторі інформаційного суспільства. Ставропігійські філософські студіi. Львів, 2009. С. 230-244.

5. Комаровська О. А. Ціннісний контекст мистецької освіти. Topical issues of pedagogy: Collective monograph. Edizioni Magi, Roma, Italia, 2019. pp.131-155.

6. Нейгауз Г. Об искусстве фортепианной игры. Записки педагога. Москва: Музыка, 1987. $238 \mathrm{c}$.

7. Реброва О. С. Методи стимулювання образотворчих та психічних процесів у майбутній виконавській діяльності вчителів музики та хореографії. Наука і освіта. 2017. Випуск 4. C. $39-45$.

8. Розвиток творчого потенціалу майбутніх фахівців мистецьких дисциплін як фактор їх професійної самореалізації : колективна монографія / Мартиненко О. В. та ін. ; за ред. А. І. Омельченко. Мелітополь: Видавничий будинок Мелітопольської міської друкарні, 2019. $361 \mathrm{c}$.

9. Рудницька О. П. Музика і культура особистості: проблеми сучасної педагогічної освіти: навч. посібник. Київ, 1998. 248 с.

10. Савкова 3. В. Искусство оратора. Москва: ИВЭСЭП; Знание, 2007. 248 с.

11. Станіславська К. І. Мистецько-видовищні форми сучасної культури : монографія. Київ: НАКККіМ, 2016. 352 c.

12. Ся Гаоян. Поліхудожня підготовка майбутнього вчителя музики: зміст, структура, орієнтири для діагностування. Молодь і ринок. Щомісячний науково-педагогічний журнал. Дрогобич, 2018. № 10 (165). С.147-151.

13. Хуан Ханьцзє. Формування готовності майбутніх учителів музики до сценічного партнерства засобами ансамблевого виконавства: автореф. дис. ... канд. пед. наук : 13.00.02 - теорія та методика музичного навчання. Нац. пед. ун-т ім. М. П. Драгоманова. Київ, 2019. 20 с.

\section{REFERENCES}

1. Bekh, I. D. (2006). Vykhovannia osobystosti: skhodzhennia do dukhovnosti [Education of personality: ascent to spirituality]. Kyiv, 272 p.[in Ukrainian].

2. Bodrova,T. O. (2017). Metodychna pidhotovka maibutnikh uchyteliv muzyky $\mathrm{v}$ konteksti universalnykh pryntsypiv zahalnoi ta mystetskoi osvity [Methodical training of future music teachers in the context of universal principles of general and art education]. Innovative processes in education: Collective monograph. AMEET Sp. z o.o., Lodz, Poland, pp. 26-39. [in Ukrainian].

3. Dikun, I.A. (2018). Formuvannia dosvidu tvorchoi diialnosti maibutnikh uchyteliv muzyky u protsesi pedahohichnoi praktyky [Formation of experience of creative activity of future music 
teachers in the process of pedagogical practice]. Extended abstract of candidate's thesis. Kyiv, $20 \mathrm{p}$. [in Ukrainian].

4. Ziaziun, I. A. (2009). Universalnist ta intehratyvnist kultury $\mathrm{v}$ osvitnomu prostori informatsiinoho suspilstva [Universality and integrative culture in the educational space of the information society]. Stauropean philosophical studies. Lviv, pp. 230-244. [in Ukrainian].

5. Komarovska, O. A. (2019). Tsinnisnyi kontekst mystetskoi osvity [Value context of art education]. Topical issues of pedagogy: Collective monograph. Edizioni Magi, Roma, Italia, pp.131-155. [in Ukrainian].

6. Neigauz,G. (1987). Ob iskusstve fortepiannoi igry. Zapiski pedagoga [On the art of piano playing. Teacher's notes]. Moscow, 238 p. [in Russian].

7. Rebrova, O. Ye. (2017). Metody stymuliuvannia obrazotvorchykh ta psykhichnykh protsesiv u maibutnii vykonavskii diialnosti vchyteliv muzyky ta khoreohrafii [Methods of stimulating visual and mental processes in the future performance of teachers of music and choreography]. Science and education, Vol. 4, pp. 39-45. [in Ukrainian].

8. Omelchenko, A. I. (Ed.). (2019). Rozvytok tvorchoho potentsialu maibutnikh fakhivtsiv mystetskykh dystsyplin yak faktory ikh profesiinoi samorealizatsii [Development of creative potential of future specialists of art disciplines as a factor of their professional self-realization]. Melitopol, $361 \mathrm{p}$. [in Ukrainian].

9. Rudnytska, O. P. (1998). Muzyka i kultura osobystosti: problemy suchasnoi pedahohichnoi osvity [Music and culture of personality: problems of modern pedagogical education]. Kyiv, 248 p. [in Ukrainian].

10. Savkova, Z. V. (2007). Iskusstvo oratora [Theartofthe publicspeaker]. Moscow; Znanie, 248 p. [in Russian].

11. Stanislavska, K. I. (2016). Mystetskovydovyshchni formy suchasnoi kultury [Art and entertainment forms of modern culture]. Kyiv, 352 p. [in Ukrainian].

12. Xia Gaoyang. (2018). Polikhudozhnia pidhotovka maibutnoho vchyteliamuzyky: zmist, struktura, oriientyry dlia diahnostuvannia [Polyartistic training of future music teacher: Content, structure, guidelines for diagnosis]. "Youth and market". Monthly scientific-pedagogical journal. Drogobych, Vol, 10 (165).pp.147-151. [in Ukrainian].

13. Huang Hanjie. (2019). Formuvannia hotovnosti maibutnikh uchyteliv muzyky do stsenichno hopartnerstva zasobamy ansamblevoho vykonavstva [Formation of readiness of future music teachers for stage partnership by means of ensemble performance]. Extended abstract of candidate's thesis. Kyiv, 20 p. [in Ukrainian].

Стаття надійшла до редакції 24.06.2020

\section{G5808902}

“भіщо не буває рано, ніщо не буває пізно. Все буває вчасно".

$$
\begin{array}{r}
\text { Конфууиій } \\
\text { давньокитайський білособб }
\end{array}
$$

“Важливо вірити, що талант нам дається не просто так- $і$ що за будь-яқу ціну його потрібно для чогось використовувати”.

Марія Склодовсъка-Кюрі франиузький педагог

“Кожне слово вихователя повинно нести в собі добро, справедливість і қрасу - и иьому суть наших повчань”.

Василь Сухоминський педагог, публіиист, письменник

"Коли вам здасться, що иіль недосяжна, не змінюйте мету - змінюйте свій план $\partial i u^{\prime \prime}$.

Конбуцій

давньокитайський білособ

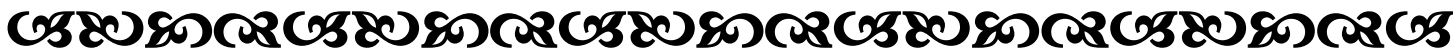

